\title{
THE INFLUENCE OF RELIGIOUSITY AND INCOME ON ZAKAT AWARENESS AND INTEREST IN PAYING ZAKAT
}

Nur Adilla ${ }^{1}$

IIJ Universitas Islam Negeri Sumatera Utara Medan, Medan, Indonesia Dillazanhmedan@gmail.com

Yenni Samri Julianti Nasution ${ }^{2}$

Universitas Islam Negeri Sumatera Utara Medan, Medan, Indonesia yenni.samri@uinsu.ac.id

\author{
Sugianto $^{3}$ \\ Universitas Islam Negeri Sumatera Utara Medan, Medan, Indonesia \\ Sugianto@uinsu.ac.id
}

\begin{abstract}
Zakat given to mustahiq will play a role as a supporter of their economic improvement if it is consumed in productive activities. The utilization of productive zakat has a concept of careful planning and implementation, such as examining the causes of poverty, lack of working capital, and lack of employment opportunities. Therefore, zakat has a very strategic role in poverty alleviation efforts or economic development. This study is a descriptive quantitative study that examines the independent, dependent, and intervening variables related to the influence of religiosity and income on interest in paying directly and indirectly through zakat awareness of zakat. Located on the street at LAZ Nurul Hayat Medan using as many as 100 mustahik. The results of the research show that the variables of religiosity and income affect the interest in paying zakat directly or indirectly through zakat awareness at LAZ Nurul Hayat Medan.
\end{abstract}

Keywords: Religiosity, Income, Awareness, Interest in Zakat 


\section{INTRODUCTION}

Zakat has a huge opportunity and potential to always be developed to alleviate poverty and poverty that exists in society and the ummah. In reality that has occurred in the field for a decade, where zakat collection has experienced rapid development and it is exciting to observe, especially from its growth. However, the increase in the growth of zakat acquisition which is very encouraging is not under the potential of zakat that should be collected. (Tho'in \& Marimin, 2019) The level of absorption of zakat in our country can be seen in the research that has been carried out by the Zakat Management Organization (OPZ), that the acquisition of zakat funds in 2015 was only $1.3 \%$ of the total potential for zakat acquisition itself..(Tho'in \& Marimin, 2019) Every human being on this earth is given the mandate to manage their assets under religious principles and provisions. So they are prohibited from wasting and wasting their wealth because in their wealth there are social rights (Supena, 2009). What is meant by social rights are the rights of other people especially the poor over their excess assets, such as paying zakat.

Data on the growth of zakat in Indonesia can be seen in the 2019 National Zakat Statistics, an annual publication of BAZNAS which presents data on the collection and distribution of zakat, infaq, alms, and DSKL funds in Indonesia. The data collection method used this year is no different from previous years, namely direct data collection from the BAZNAS Information Management System (SIMBA) application which as of 2019 has been actively used by 171 regional BAZNAS and 5 LAZs, and data collection through reports are sent manually and can be seen in the image below: (BAZNAS), 2019)

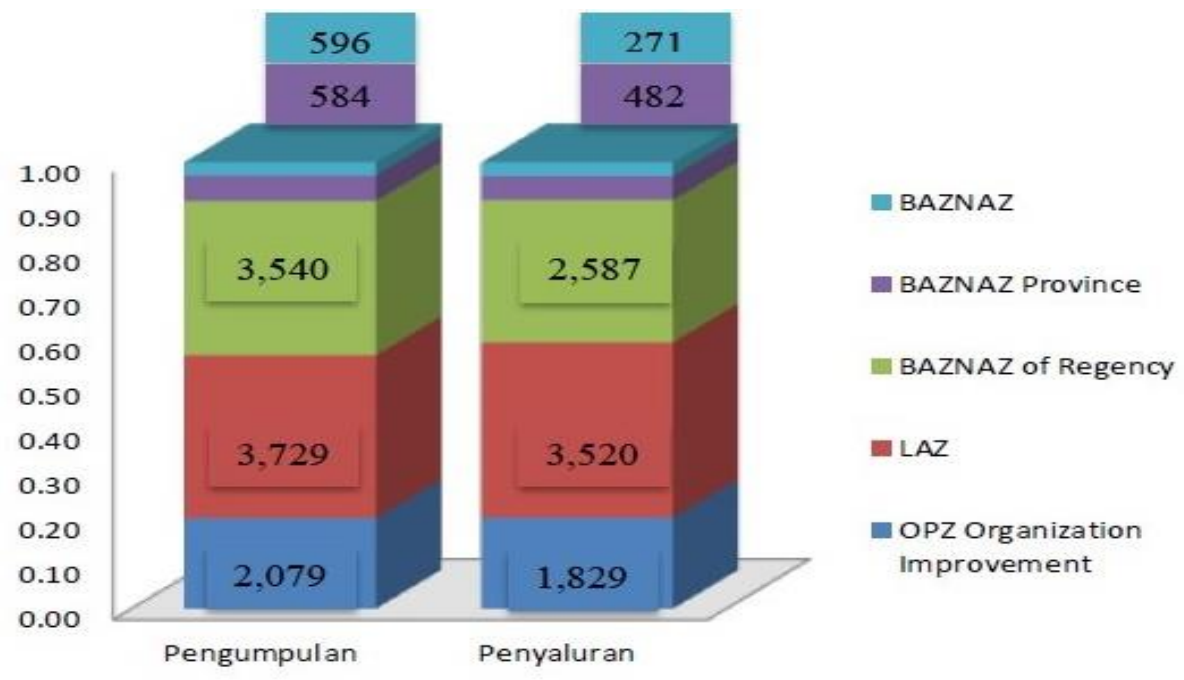

Figure 1

Collecting and Distributing of ZIS 2019 
According to figure 1 above, it can be seen that the collection of funds based on the level of the zakat management organization, where the results of the collection from OPZ in institutional development obtained results of 2.079, LAZ obtained results of 3.729, City Regency BAZNAZ obtained results of 3.540, Provincial BAZNAZ obtained results of 0.584 and BAZNAS obtained results of 0.296. It can be explained that LAZ occupies a maximum value of 3.729 and BAZNAS occupies a minimum value of 0.296.

As for the level of distribution, it can be seen that from OPZ in institutional development the results were 1.829, LAZ obtained results of 3.520, City Regency BAZNAZ obtained 2.587 results, Provincial BAZNAZ obtained results of 0.482 and BAZNAS obtained 0.271 results. It can be explained that LAZ occupies a maximum value of 3,520 and BAZNAS occupies a minimum value of 0.271 .

Furthermore, the portion of the collection based on the type of funds can be seen in the image below: ((BAZNAS), 2019)

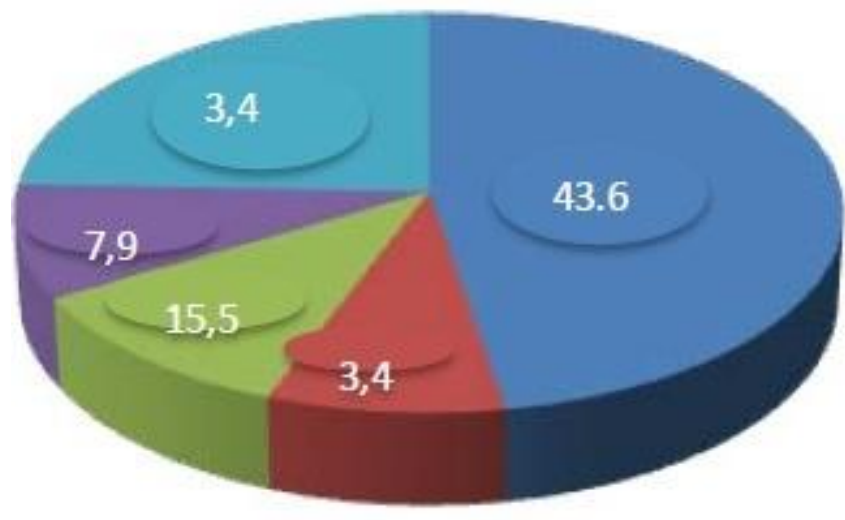

Figure 2

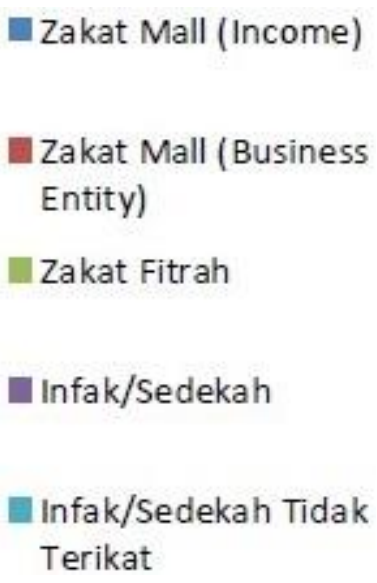

Terikat

\section{ZIS Collecting Based on Fund}

According to figure 2 above, it can be seen that the portion of the collection is based on the type of fund, where the results of Zakat Maal Income get a yield of 43.6\%, Zakat Maal Agency gets a yield of 3.4\%, Zakat Fitrah gets a yield of 15.5\%, Infaq/Unbound Alms gets a yield of $28.5 \%$, and Bound Infaq/Alms received a yield of $7.9 \%$. It can be explained that the Zakat Maal on Income obtains a maximum percentage value of $43.6 \%$, and the Zakat Maal on the Agency obtains a minimum percentage value of $3.4 \%$.

Furthermore, the benefits of zakat in Islam are that there are dimensions of benefit and economic resources in society that can be managed with very good potential. This can be created 
through improving people's welfare, which can be done through various managements and selective distribution of zakat to everyone who is entitled to receive it. Therefore, zakat is collected and there is an institution that manages the zakat, so that the aims and objectives of zakat to improve the welfare of the community can be carried out. Problems related to zakat are not a task that only one person can complete, but this is also the duty of a country, so zakat must have administrators who can take care of zakat properly and correctly who are appointed by the state. (Qardhawi, 2007)

Good zakat management is expected to be able to become sources and potential in realizing the welfare of all people. Therefore, the institution has a role and authority to increase zakat receipts. According to Law No. 23 of 2011 on Zakat management, two institutions have the task of managing, distributing, and utilizing zakat, namely the National Amil Zakat Agency (BAZNAS) and the Amil Zakat Institution (LAZ). (Kompasiana.com, 2018) The difference between the two is that BAZNAS is an institution formed by the central government to carry out the task of managing zakat nationally. Institutionally, it is independent, non-structural, domiciled in Jakarta and responsible to the President through the Minister of Religion. Meanwhile, LAZ is a zakat management institution formed at the initiative of the public.

The establishment of LAZ must obtain permission from the Minister or an official appointed by the Minister. LAZ is required to periodically report to BAZNAS on the implementation of the collection, distribution, and utilization of zakat which has been audited by sharia and finance. In addition to receiving zakat, BAZNAS or LAZ can also receive infaq, alms, and other religious social funds. The distribution and utilization of infaq, alms, and other religious social funds are carried out under Islamic law and carried out according to the designation pledged by the giver and must be recorded in a separate book. To date, there are 17 national scale LAZs that have received permits from the Ministry of Religion, one of which is Nurul Hayat's LAZ.

LAZ Nurul Hayat is a zakat institution with a decree of the Minister of Religion number 244 of 2015 concerning the granting of a permit for Nurul Hayat as a National Zakat Institution (LAZ). LAZ Nurul Hayat has 33 branches spread across 9 provinces throughout Indonesia, namely East Java, West Java, Central Java, Jabotabek Yogyakarta, East Kalimantan, South Sulawesi, South Sumatra, and North Sumatra, which are located in the city of Medan. The data for the growth of Nurul Hayat's ZIS nationally can be seen in the graph below (Hidayat, 2020): 


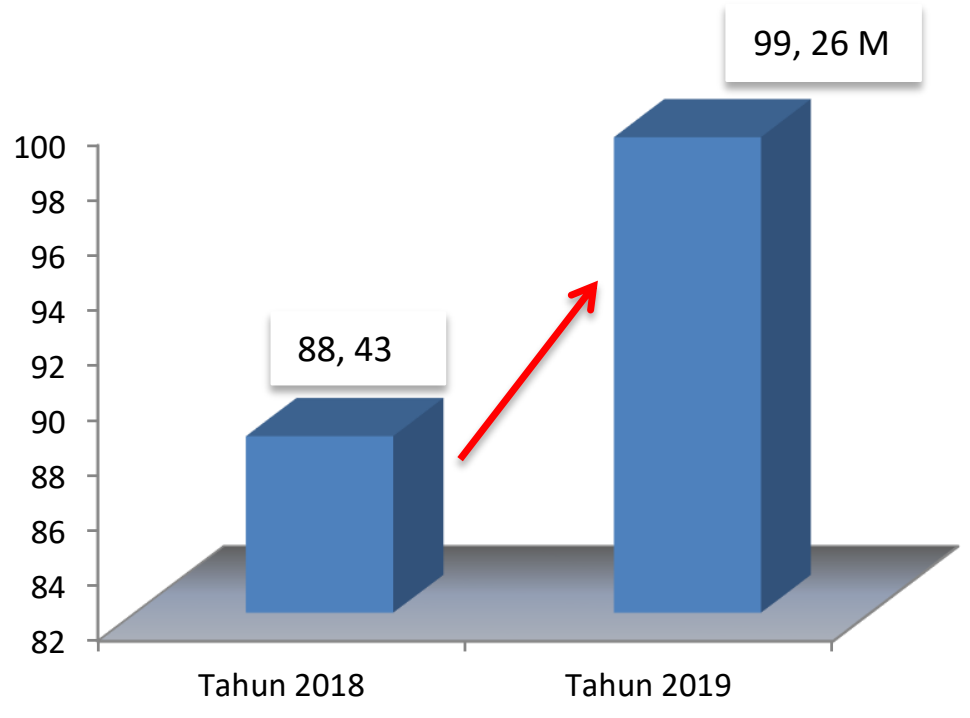

Figure 3

Growth of ZIS at Nurul Hayat

From the picture above, it can be seen that the growth data of Nurul Hayat's ZIS Nationally was $88.43 \mathrm{M}$ in 2018 and $99.26 \mathrm{M}$ in 2019. Thus, there was an increase/increase from 2018 to 2019 which was $12.2 \%$. As for later, the focus of research by LAZ researcher Nurul Hayat in North Sumatra, precisely in the city of Medan.

Zakat given to mustahiq will play a role as a supporter of their economic improvement if it is consumed in productive activities. The utilization of productive zakat has a concept of careful planning and implementation such as examining the causes of poverty, lack of working capital, and lack of employment opportunities, with these problems it is necessary to have a plan that can develop productive zakat. Productive zakat is also very effective in alleviating poverty, especially in areas where the majority of the people are engaged in agriculture, livestock, and other informal sectors. (Komariyah \& Kunaifi, 2020) It was emphasized in the research that zakat has a very strategic role in poverty alleviation efforts or economic development, contextually productive zakat has proven to be significant in alleviating poverty. In contrast to other sources of finance for development, zakat does not have any repercussions except pleasure and hoping for a reward from Allah SWT alone. However, it does not mean that the zakat mechanism does not have a control system.

Zakat must be distributed to mustahik under Islamic law. The distribution is carried out based on a priority scale by taking into account the principles of equity, justice, and territoriality. Zakat can be utilized for productive efforts in the context of handling the poor and improving the 
quality of the people if the basic needs of mustahik have been met. To increase usability and usability, zakat must be managed institutionally under Islamic law, trustworthiness, expediency, justice, legal certainty, integration, and accountability to increase the effectiveness and efficiency of services in zakat management. In the current pandemic situation, optimization of productive zakat to empower the affected community is very much needed. The productive zakat instrument can be categorized as the implementation of religiosity as a form of community responsibility in empowering individuals or families (Kunaifi, 2020).

Based on the description of the problem above, this study aims to determine the effect of religiosity on interest in paying zakat, the effect of income on interest in paying zakat, the effect of awareness of paying zakat on interest in paying zakat, the influence of religiosity on interest in paying zakat through awareness of zakat, the effect of income on interest in paying zakat. through awareness of zakat awareness, the influence of religiosity and income on interest in paying zakat, and the influence of income religiosity and zakat awareness on interest in paying zakat at LAZ Nurul Hayat Medan.

\section{REVIEW OF LITERATURE}

\section{Definition of Zakat}

In language, zakat means to grow (nитmиw) and increase (ziyadah). If pronounced, zaka al-zar means that the plant grows and increases. If you say zakat al-nafaqah, it means that your living will grow and increase if you are blessed. As for zakat according to syara', it means a right that must be removed from the property. (Zuhayli (Az), 1995) And al-barakatu which means blessing, ath-thaharatu which means purity, al-namaa which means growth and development, and ash-shalahu which means order. While zakat according to the term many scholars argue with different editorials but have the same intention, namely that zakat is part of the property with certain conditions, which Allah SWT obliges the owner to be handed over to someone who is entitled to receive it. , with certain conditions too. (Hafidhuddin, 2002)

\section{Utilization of Zakat, Infaq, and Sadaqah}

Utilization of zakat, infaq, and shadaqah is a form of maximum utilization of zakat, infaq, and shadaqah funds without reducing their value and usefulness, so that they are efficient to achieve the benefit of the people..(Khasanah, 2010) Utilization of zakat, infaq and shadaqah 
functions as a social concept, this utilization is expected to create understanding and awareness as well as sustainable economic development.

The principle of utilizing zakat for mustahiq is carried out with the provisions; the results of data collection and research on the truth of mustahiq eight ashnaf, prioritize people who are most helpless in meeting basic needs economically and in dire need of assistance and prioritize mustahiq in their respective areas. (Soemitra, 2009)

The procedures for utilizing the collection of zakat proceeds for productive businesses are based on; conducting feasibility studies, determining the type of productive business, conducting guidance and counseling, monitoring, controlling and supervising, conducting evaluations, and making reports. (Soemitra, 2009) If the public already understands the distribution of zakat, of course, the distribution is not complicated, because the distribution is known, although it still requires accuracy and precision of the zakat amil.

\section{Zakat, Infaq, dan Shadaqah In Productive Applied}

There are two categories of zakat distribution management applied in Indonesia, namely consumptive distribution and product distribution. The development of the zakat distribution method, which is currently experiencing rapid development, has become an object of scientific study and its application in various zakat institutions, namely the method of productive utilization..

According to Abdurrachman Qadir, productive zakat is zakat given to mustahiq as capital to carry out an economic activity, namely, to develop the economic level and productivity potential of mustahiq. (Qadir, 2001) Productive shadaqah are zakat, infaq and shadaqah funds given to mustahiq in the form of business capital that helps capital in various forms of community economic activity and the development of businesses for the lower middle class or economically weak groups who do not have capital.

To achieve maximum, effective, and efficient results, the model and mechanism for the utilization of productive zakat are structured in such a way by an amil agency that resembles an economic business entity that helps capital in various forms, community economic activities, and the development of businesses of the weak economy, especially the poor. Generally, those who are unemployed or do not try optimally because of lack of capital, this is given in the form of business capital, zakat infaq and shadaqah funds which are also rolled out to other mustahiq, and so on until all the poor can be independent in building their economic life. (Qadir, 2001) 
Giving zakat, infaq and productive shadaqah in the form of business capital also have a positive impact on increasing productive zakat income. For example, the provision of productive zakat, infaq, and shadaqah funds in the form of business capital have a positive impact on increasing community business income. Increasing the business of zakat recipients, infaq, and productive shadaqah in the form of venture capital has an impact on increasing income, fulfilling the basic needs of the community, and reducing the number of poverty rates in one district. (Komariyah \& Kunaifi, 2020)

\section{Islam and Poverty Alleviation}

Islam has a clear concept in overcoming poverty. Alleviating poverty is a command and recommendation from Allah through the obligation of zakat, fond of charity, giving infaq, waqf, and others. Allah made zakat a source of guarantee for the rights of the poor. Al-Qur'an and hadith always mention prayer and zakat together. This shows the obligation and the close relationship between the two. Because prayer is a pillar of religion. While zakat is a cleanser of the heart and property, as well as the support for the establishment of Islam. Paying zakat is one of the characteristics of believers who always do good and fear Allah, on the other hand, those who refuse zakat are characteristics of polytheists and hypocrites.

Regarding the problem of poverty alleviation, Yazid bin Abdullah Qadir Jawas wrote about Islamic tips to overcome poverty, including; work and try, provide for weak families, zakat, voluntary alms, and individual Muslim policies, social endowments in the form of jariyah and the like. (Qadir, 2001) In the context of macroeconomics, zakat, infaq, shadaqah, and waqf are part of the instruments to create prosperity. Zakat, infaq, shadaqah, and waqf are philanthropic (non-profit) products that are the shared responsibility of the three components in society in creating an equitable distribution of wealth. Through an even distribution of purchasing power or public consumption, it will be maintained, so that in addition to solving the basic needs of individuals and families, it also minimizes inequality and creates prosperity..(Kunaifi, Rahman, \& Dwiaryanti, 2021) The welfare context in question does not only apply to the Indonesian community, which is predominantly Muslim, but is also relevant to other countries as research conducted in another countries. (Lahjouji \& Rouggani, 2016) 


\section{Zakat Theological Basis}

Zakat is one of the five pillars of Islam which should carry it out. Zakat also shows that Islam is very concerned about the relationship between humans and God (Hablun min Allah) and human relations (Hablun min al-nas).(Nuruddin, 2006)

The legal basis for the obligation to issue zakat refers to the following verses:

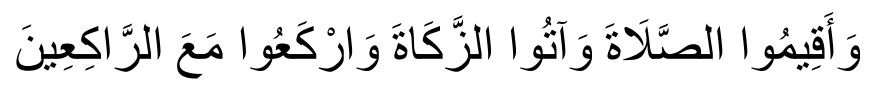

"And establish prayer, pay zakat and bow with those who bow". (Q.S. 2 : 43) (alQardhawi, 2000)

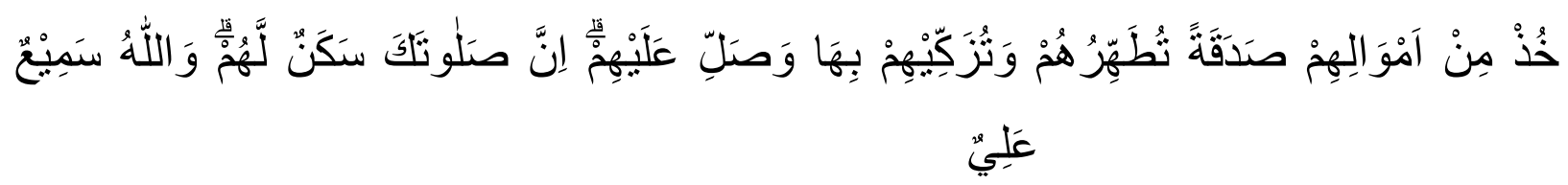

"Take zakat from some of their wealth, with your zakat you clean and purify them, and pray for them. Verily, your prayer (becomes) peace of mind for them. And Allah is AllHearing, All-Knowing.". (Q.S. 9 : 103) (al-Qardhawi, 2000)

As part of fiscal policy, zakat has been proven to be effective as an instrument of fiscal policy for economic stability. (Saputra, Kunaifi, \& Rosyid, 2021). In community economic activities, zakat, infaq, and shadaqah are the main sources of state income which will later be distributed as subsidies to 8 ashaf. (Kunaifi, 2018) From the explanation above, zakat is a property that must be issued. Zakat will purify the person who gives it and will grow his reward. Zakat makes some special assets from special assets as the property of a special person, which is determined by the Shari'ah because of Allah. The word to make some property as property (tamlik) in the above definition is intended as an avoidance of the word worship (permissibility). Zakat is an expression for the discharge of property or body in a special way. Zakat is an obligatory right (issued) from a special property for a special group (Zuhayli (Az), 1995).

\section{RESEARCH METHOD}

This research is a type of research that uses a quantitative approach. That is, in this study the data analysis used is statistical data analysis. Meanwhile, the nature of this research is correlation research, which is looking for the relationship between one variable and another variable. Because this research involves indicators in variables, namely $\mathrm{X} 1$ variable, $\mathrm{X} 2$ variable, $\mathrm{X} 3$ variable, and $\mathrm{Y}$ variable. In terms of $\mathrm{X} 1$ variables include religiousity, $\mathrm{X} 2$ variable is 
awareness of the obligation of zakat (intervening variable), $\mathrm{X} 3$ variable is income and $\mathrm{Y}$ variable is the dependent variable of interest in paying zakat.

For the objectivity and accuracy of this study, data were collected through a questionnaire instrument which was then analyzed to obtain a clear picture of the object. The research location was carried out at the national amil zakat institution, Nurul Hayat, Medan. With a sample of 100 muzakki people. The sampling technique used is a random technique, in connection with this sample study, Arikunto stated that if the subject is less than 100, it is better to take all of them so that the research is a population study. Furthermore, if the number of subjects is large, it can be taken between 10-15\% 20-25\%, or more. (Arikunto, 2010) Sampling in this study was $10 \%$ of 178 mustahiq people, and it was 18 people. then this amount is used as a sample and object to be studied. Then the type of data used is Primary Data, namely data obtained using an instrument or questionnaire (questionnaire).

\section{RESULTS AND DISCUSSION}

To describe the causal or causal relationship between the variables to be investigated, the researcher uses a path diagram model. A path diagram is a tool to graphically describe the structure of cause-and-effect relationships between independent variables, traversed variables, and variables. It's shown as path below:

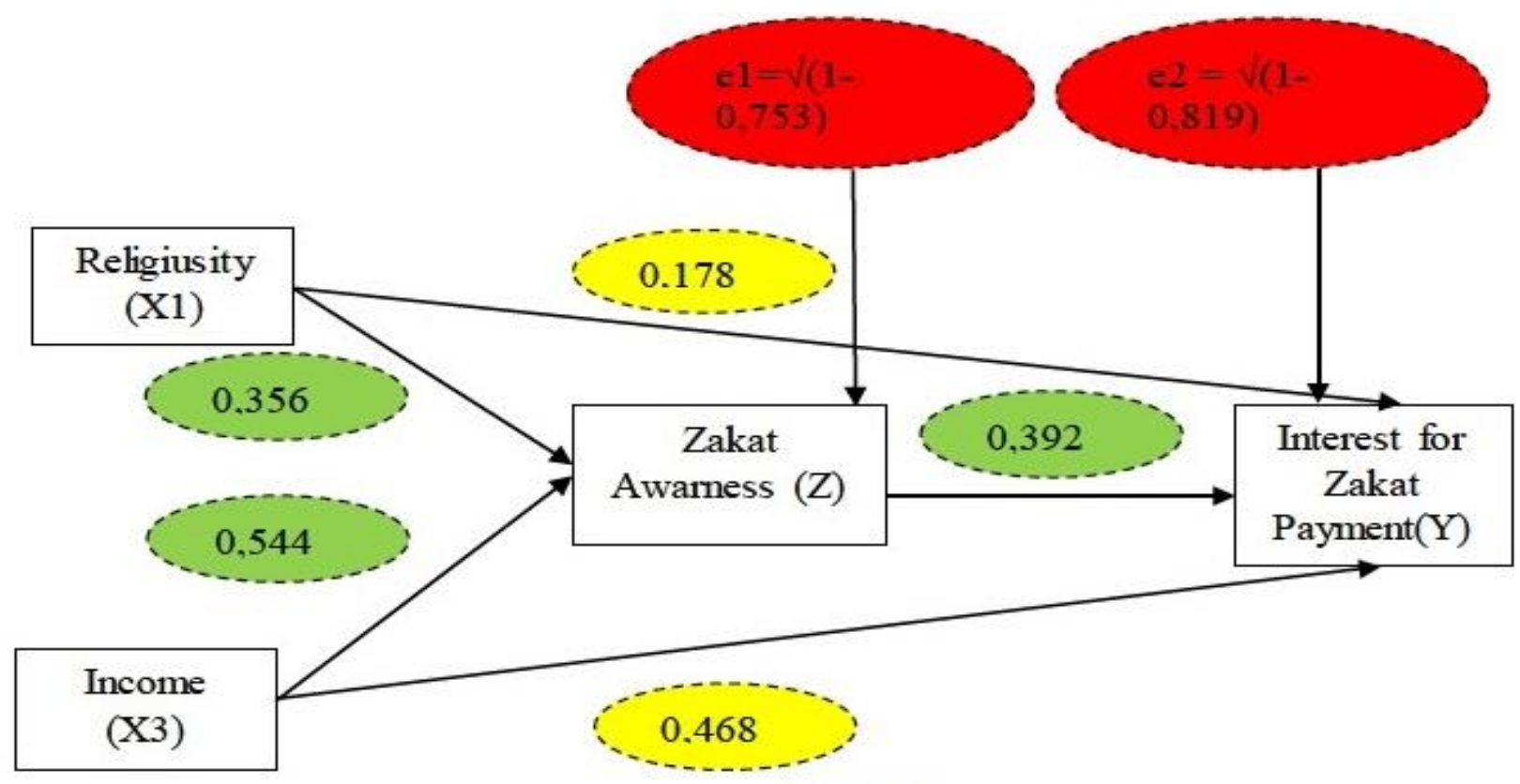

Figure 4

Path Analysis 


\section{Table 1}

\section{Result of Path Analysis}

\begin{tabular}{lrrr}
\hline & $\begin{array}{c}\text { Direct } \\
\text { Influence }\end{array}$ & $\begin{array}{c}\text { Undirect } \\
\text { Influence }\end{array}$ & $\begin{array}{c}\text { Total } \\
\text { Infulence }\end{array}$ \\
\hline $\mathrm{X}_{1} \rightarrow \mathrm{Z}$ & 0,356 & & \\
$\mathrm{X}_{1} \rightarrow \mathrm{Y}$ & 0,178 & & \\
$\mathrm{X}_{2} \rightarrow \mathrm{Z}$ & 0,544 & & \\
$\mathrm{X}_{2} \rightarrow \mathrm{Y}$ & 0,468 & & \\
$\mathrm{Z}$-> Y & 0,392 & & \\
$\mathrm{X}_{1} \rightarrow \mathrm{Z}$-> Y & & $0,356 \times 0,392=0,1395$ & $0,356+0,1395=0,4955$ \\
$\mathrm{X}_{2} \rightarrow \mathrm{Z}$-> Y & & $0,544 \times 0,392=0,2132$ & $0,544+0,2132=0,7572$
\end{tabular}

Source: Data Processed, 2021

Based on the results of the above calculations, it is known that the value of the direct influence of $X_{1}$ is 0.178 and the indirect effect is 0.1395 , which means that the value of the indirect effect is greater than the direct effect, these results indicate that $\mathrm{X}_{1}$ through $\mathrm{Z}$ indirectly influences Y.

Based on the results of the above calculations, it is known that the value of the direct influence of $\mathrm{X}_{2}$ is 0.468 and the indirect effect is 0.2132 , which means that the value of the indirect effect is greater than the direct effect, these results indicate that $\mathrm{X}_{2}$ indirectly through $\mathrm{Z}$ influences $\mathrm{Y}$. It can be concluded that the variables $\mathrm{X}_{1}$ and $\mathrm{X}_{2}$ have a direct influence on the $\mathrm{Y}$ variable and have an indirect effect on the $\mathrm{Y}$ variable through the $\mathrm{Z}$ variable. For more details, the researcher clarifies the results of the direct and indirect effects below.

\section{Religion Affects Interest in Paying Zakat at LAZ Nurul Hayat Medan}

From the results of the Y statistical T-test in the table above, it can be seen that religiosity $\left(\mathrm{X}_{1}\right)$ is 2.062 with a significance probability value of $0.04<0.05$, it can be said that there is a significant influence on interest in paying zakat $(\mathrm{Y})$, and it can be concluded that $\mathrm{H}_{\mathrm{a}}$ is accepted. where there is a significant influence between religiosity variables on interest in paying zakat In an Islamic perspective, religiosity is an activity related to social, political and economic and other activities in surrendering to Allah The level of religiosity of a person can be interpreted as devotion in religion, among many factors One of the factors that cause success or failure in collecting zakat is the religious condition of a person. 


\section{Income Affects Interest in Paying Zakat at LAZ Nurul Hayat Medan}

From the results of the Y statistical T-test in the table above, it can be seen that income $\left(\mathrm{X}_{2}\right)$ is 4.697 with a significant skill value of $0.00<0.05$, it can be said that there is a significant effect of interest in paying zakat. and it can be concluded that $\mathrm{Ha}$ is accepted where there is a significant influence between income variables on interest in paying zakat. Every human being on this earth is given the mandate to manage their assets under religious principles and provisions. So that they are prohibited from wasting and wasting their wealth because in their wealth there are social rights. What is meant by this social right is the right for other people (especially the poor) over their excess assets, such as paying zakat.

\section{Awareness Affects Interest in Paying Zakat at LAZ Nurul Hayat Medan}

From the results of the $\mathrm{Y}$ statistical T-test in the table above, it can be seen that zakat awareness $(Z)$ is 4.600 with a significant probability value of $0.00<0.05$, it can be said that there is a significant influence on interest in paying zakat (Y). concluded that $\mathrm{Ha}$ is accepted where there is a significant influence between the variables of zakat awareness on interest in paying zakat. Awareness in fulfilling obligations is in line with an adequate level of understanding about the obligations of a Muslim regarding zakat. This is very important so that one's understanding and knowledge regarding the rules in Islamic teachings can be implemented.

\section{Religion Affects Interest in Paying Zakat Through Zakat Awareness At LAZ Nurul Hayat Medan}

Based on the calculation results, it is known that the value of the direct influence of religiosity $\mathrm{X}_{1}$ is 0.178 and the indirect effect is 0.1395 , which means that the value of the indirect influence is greater than the direct effect. the interest in paying zakat Y. As a maliyah worship, the command to pay zakat in the Qur'an has been written explicitly and implicitly, including hand in hand with the command to establish prayer, Allah's commandment about zakat in the Qur'an means how important the value of zakat in Islam is.

\section{Income Affects Interest in Paying Zakat Through Zakat Awareness At LAZ Nurul Hayat Medan}

Based on the calculation results, it is known that the value of the direct influence of $\mathrm{X}_{2}$ 's income is 0.468 and the indirect effect is 0.2132 , which means that the value of the indirect effect is large compared to the direct effect. interest in paying zakat Y. Income is compensation 
obtained or obtained through various work activities that are under sharia by a person in meeting the needs of life.

\section{Religiosity and Income Affect Zakat Awareness at LAZ Nurul Hayat Medan}

Based on the test results in the table above, it shows that the F value is 20.206 with a significant probability level of 0.00 and the significance probability value is much less than 0.05 , so the regression model can be used to predict the religiosity and income variables together (simultaneously). ) has a significant effect on the zakat awareness variable. Utilizing a joint relationship between religiosity and income, to awareness of zakat, which is interrelated.

\section{Income religiosity and zakat awareness affect interest in paying zakat at LAZ Nurul Hayat} Medan

Based on the test results in the table above, it shows that the $\mathrm{F}$ value is 72.811 with a significant probability level of 0.00 and the significance probability value is much less than 0.05 , so the regression model can be used to predict the variables of religiosity, income and zakat awareness together. (simultaneously) has a significant effect on the variable of interest in paying zakat. By means of a joint relationship - religiosity, income, and awareness of zakat on interest in paying zakat are interrelated.

\section{The urgency of Literacy in Increasing Interest in Paying Zakat}

The significance of religiosity and income on interest in paying zakat through the intervening variable awareness of the obligation of zakat is a very rational natural phenomenon. In the aspect of income as a factor that influences interest in paying zakat, it is a shared obligation, both individuals through work ethic, families through inheritance responsibilities and partnerships, and of course the state through job creation and industry. So that the most relevant thing done by LAZ Nurul Hayat Medan and other amil zakat institutions to increase religiosity and awareness of zakat obligations is to carry out zakat literacy inclusion and intensification programs. A good understanding of zakat obligations through studies or taklim will make it easier for LAZ management to realize their duties in collecting zakat funds. Various studies have also proven that literacy and various inclusion programs can increase public interest in various Islamic financial products. (Kunaifi, 2016), see also (Kunaifi, Jannah, \& Setianto, 2020). 


\section{CONCLUSION}

The results of this study indicate that there is an influence of religiosity and income on zakat awareness and interest in paying zakat at LAZ Nurul Hayat Medan. Thus, there is a relationship between religiosity and income, awareness of zakat, and interest in paying. Therefore, every zakat management carried out by the institution must strive to increase and maximize the zakat received. On the other hand, zakat institutions must also be able to seek the interest (desire) of paying zakat by muzakki. In addition, the lack of involvement of muzakki as stakeholders is an inhibiting factor for the lack of willingness of muzakki to pay their zakat to zakat institutions. One of the relevant efforts is to carry out literacy and zakat inclusion programs for prospective muzakki.

Furthermore, the researcher realizes that this research is inseparable from several shortcomings made by the researcher, one of which is still at least the independent variables used in this study. Therefore, further research is recommended to add other independent variables that may affect zakat awareness and interest in paying zakat. because there are many factors - factors that influence it.

\section{REFERENCES}

al-Qardhawi, Y. (2000). Norma dan Etika Ekonomi Islam (Terjemahan dari Daurul Qiyam wal Akhlaq fi al-Iqtishadi al-Islami). Jakarta: Gema Insani Press.

Arikunto, S. (2010). Prosedur Penelitian (16 ed.). Bandung: Remaja Rosdakarya.

(BAZNAS), B. A. Z. N. (2019). Statistik Zakat Nasional. BAZNAS Sub Divisi Zakat.

Hafidhuddin, D. (2002). Zakat dalam Perekonomian Modern. Jakarta: Gema Insani.

Hidayat, N. (2020). Lembaga Amil Zakat Nasional. LAS Nasional.

Khasanah, U. (2010). Manajemen Zakat Modern. Malang: UIN Maliki Press.

Komariyah, N., \& Kunaifi, A. (2020). Pengaruh Pendayagunaan Zakat, Infaq dan Shadaqah Produktif Terhadap Pengurangan Angka Kemiskinan (Studi Pada LAZIS Muhammadiyah Pamekasan): Studi Pada LAZIS Muhammadiyah Pamekasan. CENDEKIA: Jurnal Studi Keislaman, 6(2), 149-165.

Kunaifi, A. (2016). Optimalisasi Laboratorium Keuangan Syariah Dalam Meningkatkan Literasi Civitas Akademika Terhadap Produk IKNB Syariah. CENDEKIA: Jurnal Studi Keislaman, 2(2), 221-239. https://doi.org/10.37348/cendekia.v2i2.27 
Kunaifi, A. (2018). Telaah Kritis Kebijakan Fiskal Perspektif Kaidah Fiqh. Proceedings International Seminar, The 3rd Annual International on Islamic International Education, 3(1) (2018): Seri-1), 21.

Kunaifi, A. (2020). Empowerment Ekonomi Publik Dalam Mengatasi Resesi Dampak Pandemi. Dalam 1: Vol. 1. Perspektif Multidisipliner dalam Pelaksanaan Adaptasi Kebiasaan Baru (1 ed., Vol. 1, hlm. 3-12). Tulungagung: Akademia Pustaka.

Kunaifi, A., Jannah, J., \& Setianto, A. W. E. (2020). Literasi Civitas Akademika Di Pamekasan Terhadap Produk Industri Keuangan Syariah. AL-IQTISHADY: Jurnal Ekonomi Syariah, $1(2), 1-21$.

Kunaifi, A., Rahman, F., \& Dwiaryanti, R. (2021). The Philosophy and Authentication of Welfare Equalization in the Islamic Economy. Jurnal Kajian Peradaban Islam, 4(2), 5462. https://doi.org/10.47076/jkpis.v4i2.67

Lahjouji, H., \& Rouggani, K. (2016). Zakat and Distribution of Wealth on Islamic Economy: Case of Morocco. International Journal of Islamic Economics and Finance Studies, 2(3), $151-160$.

Nuruddin, M. A. (2006). Zakat sebagai instrumen dalam kebijakan fiskal. Jakarta: Raja Grafindo Persada.

Qadir, A. (2001). Zakat Dalam Dimensi Mahdah dan Sosial. Jakarta: Rajagrafindo Persada.

Qardhawi, Y. (2007). Hukum Zakat (Terjemahan ed. 10). Jakarta: Mitra Kertajaya Indonesia.

Saputra, T. A., Kunaifi, A., \& Rosyid, A. (2021). Benarkah Kebijakan Fiskal Islam Efektif Menghadapi Resesi? (Kontekstualisasi Kebijakan Fiskal Sesuai Shariah). Prosiding Seminar STIAMI, 8(1), 1-6.

Soemitra, A. (2009). Bank dan Lembaga Keuangan Syariah. Jakarta: Prenada Media.

Tho'in, M., \& Marimin, A. (2019). Pengaruh Tingkat Pendapatan, Tingkat Pendidikan, dan Tingkat Religiusitas Terhadap Minat Muzakki Membayar Zakat. Jurnal Ilmiah Ekonomi Islam, 5(3), 225-230.

Zuhayli (Az), W. (1995). Zakat Kajian Berbagai Mazhab. Bandung: Remaja Rosdakarya. 